\title{
EVERSION AND INVERSION OF THE DORSO-LATERAL WALL IN DIFFERENT PARTS OF THE BRAIN.
}

\author{
B Y
}

C. U. ARI ̈̈NS KAPPERS, Amsterdam.

Wițh Five Figures.

In the Anatomische Anzeiger, $B d . \mathrm{xxx}, \mathrm{1} 907$, and in a more extensive way in the Folia Neuro-biologica, Heft 2, I908, TheuNISSEN and I have given a comparative description of the different forms of forebrain, as they occur in vertebrates, from which it resulted that in Cyclostomes and in Selachians the upper part of the lateral wall of the forebrain is bent in a medio-dorsal direction, forming a sort of pallium, whereas in Ganoids and Teleosts this same part is bent ventro-laterally, so that the primitive brainmantle which is inverted in the former is everted in the latter. I further called attention to the fact that this primitive mantle should be called palco-pallium, as it is older than the archipallium, receiving only secondary olfactory fibers, whereas the archipallium receives tertiary olfactory fibers, and further that in those animals where the palæo-pallium is everted it is always greatly reduced in size compared to the inverted palæo-pallium of Cyclostomes and especially of Selachians, and that this reduction of the palæo-pallium gives rise to the formation of the medial epistriatum ${ }^{1}$ of Ganoids and Teleosts, which has a vicarious function. For this reason we find either a large and inverted palæo-pallium and a feebly developed epistriatum or an everted palæo-pallium and a large epistriatum.

The ontogenetic development of the prosencephalon in Ganoids (Allis, v. KupFFER) makes it probable to me that these differences find their origin in the form of the skull in embryos, which in a certain stage of development probably pressed on the brain, so that an extensive growth of the dorso-lateral part of the forebrain wall was made impossible. The ventral part of it took then a great deal of its function by means of an enlargement of the striatum

${ }^{1}$ Not visible in Fig. 2, which is drawn after a section anterior to the epistriatum. 


\section{Fournal of Comparative Neurology and Psychology.}

(epistriatum) by which again the dorso-lateral wall was more pushed in a ventro-lateral direction.

That really the large epistriatum is an important factor for the eversion of the dorso-lateral forebrain wall is clearly proved by the Teleosts, where the epistriatum on an average is larger than in the Ganoids, and consequently the eversion of the palæopallium is also more striking, The same is seen in one of the bony Ganoids, Amia calva, where the epistriatum is larger in the middle of the forebrain, where consequently the eversion of the latero-dorsal brain wall is also more striking ${ }^{2}$ than in the frontal

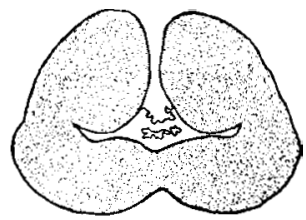

FIG. I.

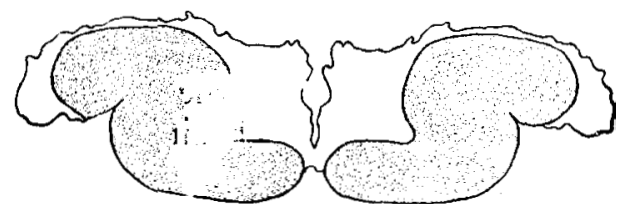

FIG. 2.

FiG. I. Frontal section through the posterior part of the forebrain of Galeus canis.

Fig. 2. Frontal section through the anterior part " the forebrain of Amia calva.

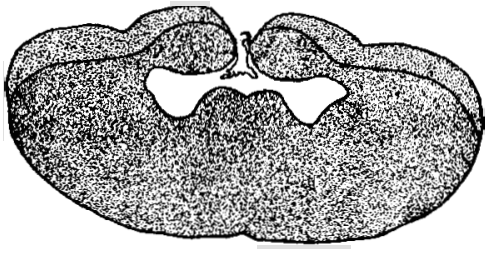

FIG. 3 .

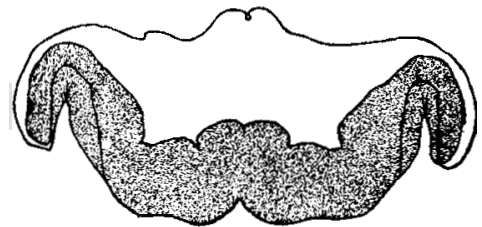

FIG. 4.

Fig. 3. Frontal section through the medulla oblongata of Galeus canis.

Fic. 4. Frontal section through the medulla oblongata of Hexanchus griseus.

or caudal parts of the fore-brain. These differences and homologies were proved by an exact study of the course of the afferent forebrain tracts, which (namely, the tr. tæniæ) proved that this interpretation was right.

Nearly the same ideas about the different forms of forebrain have been published by STudnicka, who however gave only morphological proofs for this conception and whose interpretations were not generally, or rather were generally not, accepted, probably because the conception of a palæo-pallium was never

${ }^{2}$ Chimæra monstrosa has a forebrain of which the morphology shows both forms of development, as in the frontal part of the forebrain the palæo-pallium is large and inverted, whereas in the posterior part of it, it is everted and reduced. 
exactly defined; and he with Friedrich Meyer regarded the olfacto-habenular tract, which in Cyclostomes for the greater part originates in the palæo-pallium, as a homologue of the cortico-habenular tract of Reptiles and Mammals, not making an exact distinction between the pallium of fishes and the archipallium of higher vertebrates, which was not right, an archipallium and archicortex being entirely absent in the former. Amongst others Prof. J. B. JohNSTON criticised this point of STUDNICKA's work and I can only join him in this. ${ }^{3}$

Referring for the description of the forebrain tracts in different animals (I studied the vertebrate series from the Cyclostomes to the Chiroptera) to my work in the Folia Neuro-biologica, I here only want to draw attention to the fact that the differences above mentioned for dorso-lateral forebrain wall also occur in other parts of the. 1 .

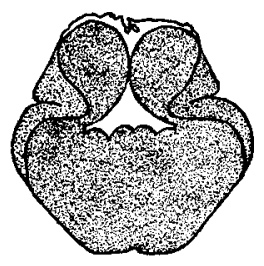

FIG. 5.

Fig. 5. Frontal section through the medulla oblongata of Chimæra monstrosa.

If we compare figs. I and 2, which represent two different forebrain types (Galeus canis and Amia calva) with figs. 3 and 4 which are made after sections through the medulla oblongata of different Plagiostomes, we see at once that the same contrast concerning the form of the dorso-lateral wall is also present between the hindbrain of Galeus canis on one side and Hexanchus griseus on the other.

The nucleus of the nervus lateralis anterior, which in most sharks is bent inward, so that it lies under the cerebellum, is turned outward in Hexanchus, and Chimæra monstrosa (fig. 5) exhibits a character which keeps about the middle between these extreme forms, as the same nucleus, though inverted, is not nearly

\footnotetext{
3 On the other hand I do not consider Professor Johnston's nomenclature, as far as concerns this question, very happily chosen, as he would better make a difference between the epistriatum of fishes and the primitive mantle-portion, palæo-pallium, which morphologically are very different things.
} 


\section{$43^{6}$ Fournal of Comparative Neurology and Psychology.}

as far inverted in this animal as it is in Galeus, Mustelus, Scyllium and other sharks.

Contrary, however, to what is seen in the forebrain, that the eversion always accompanies a reduction of the palæo-pallium, the nucleus nervi lateralis anterior in Hexanchus is not smaller than in other sharks, or, better, this nucleus in Galeus and other Selachians is not larger than in Hexanchus, being never very large in transverse sections (in comparison with inverted palæopallium forms) so that reduction of its size and a replacing of its function, for instance, by further development of the end-region of the VIII and posterior lateral nerve seems not at all necessary in this case. It is not easy to say which factor exactly has caused this strange position of the nucleus lateralis anterior in Hexanchus; it might be a traction in the lateral direction by the anterior lateralis root, about which, however, we have no certainty.

STUDNICKA

\section{LITERATURE CITED.}

Beiträge zur Anatomie und Entwickelungsgeschichte des Vorderhirns der Cranioten. Sitzungsberichte der böhmischen Gesellschaft der Wissenschaften. Mathem.-naturwissenschaftliche Classe. $1895,1896$.

Nach einige Worte zu meinen Abhandlungen über die Anatomie des Vorderhirns. Anat. Anzeiger, Bd. I3. 1898 .

The Brain of Acipenser. Fischer, Fena, Igor.

The nervous system of vertebrates. P. Blakiston's Son \& Co., Philadelphia. 1906. AriËns Kappers.

The structure of the teleostean and selachian brain. Fournal of Comparative Neurology and $\boldsymbol{P}_{\text {sychology, vol. I6. Igo6. }}$

Untersuchungen über des Gehirn der Ganoiden Amia calva und Lepidosteus osseus. Abhandlungen der Senckenbergischen Naturforschenden Gesellschaft in Frankfurt a/M. Bd. 30. 1907 .

Ariëns Kappers and Theunissen.

Zur vergleichenden Anatomie der Vorderhirns der Vertebraten. Anat. Anzeiger. Bd. 30. I907.

Arï̈ns Kappers (unter Mitwirkung von Theunissen).

Die Phylogenese des Rhinencephalons, des Corpus striatum und der Vorderhirn commissuren. Folia Neuro-biologica. Heft 2, 1908. (W. Klinkhardt, Leipzig.)

Allis.

The cranial muscles and cranial and first spinal nerves in Amia calva. Fournal of Morphology, vol. 12. 1897 .

v. KUPFFER.

Die Morphogenie des Central-nervensystems. (Abdruck aus dem Handbuch der vergleichenden und experimentellen Entwickelungsgeschichte der Wirbelthiere von O. Hertwig. Bd. II). 